\title{
Seasonal variations of virus- and nanoflagellate-mediated mortality of heterotrophic bacteria in the coastal ecosystem of subtropical western Pacific
}

\author{
A. Y. Tsai ${ }^{1}$, G.-C. Gong ${ }^{1,2,3}$, and J. Hung ${ }^{1}$ \\ ${ }^{1}$ Institute of Marine Environmental Chemistry and Ecology, National Taiwan Ocean University, Keelung 202-24, Taiwan, \\ Republic of China \\ ${ }^{2}$ Center of Excellence for Marine Bioenvironment and Biotechnology, National Taiwan Ocean UniversityKeelung 202-24, \\ Taiwan, Republic of China \\ ${ }^{3}$ Taiwan Ocean Research Institute, National Applied Research Laboratories, Kaohsiung, Taiwan, Republic of China
}

Correspondence to: A. Tsai (anyitsai@mail.ntou.edu.tw)

Received: 29 October 2012 - Published in Biogeosciences Discuss.: 6 December 2012

Revised: 6 April 2013 - Accepted: 11 April 2013 - Published: 6 May 2013

\begin{abstract}
Since viral lysis and nanoflagellate grazing differ in their impact on the aquatic food web, it is important to assess the relative importance of both bacterial mortality factors. In this study, an adapted version of the modified dilution method was applied to simultaneously estimate the impact of both virus and nanoflagellate grazing on the mortality of heterotrophic bacteria. A series of experiments was conducted monthly from April to December 2011 and April to October 2012. The growth rates of bacteria we measured ranged from $0.078 \mathrm{~h}^{-1}$ (April 2011) to $0.42 \mathrm{~h}^{-1}$ (September 2011), indicating that temperature can be important in controlling the seasonal variations of bacterial growth. Furthermore, it appeared that seasonal changes in nanoflagellate grazing and viral lysis could account for $34 \%$ to $68 \%$ and $13 \%$ to $138 \%$ of the daily removal of bacterial production, respectively. We suggest that nanoflagellate grazing might play a key role in controlling bacterial biomass and might exceed the impact of viral lysis during the summer period (July to August) because of the higher abundance of nanoflagellates at that time. Viral lysis, on the other hand, was identified as the main cause of bacterial mortality between September and December. Based on these findings in this study, the seasonal variations in bacterial abundance we observed can be explained by a scenario in which both growth rates and loss rates (grazing + viral lysis) influence the dynamics of the bacteria community.
\end{abstract}

\section{Introduction}

It is well recognized that both viral lysis and protozoan grazing are important top-down controls of bacterial mortality in oceanic systems (Pace, 1988; Wilhelm et al., 2002; Taira et al., 2009). When bacterial cells are grazed, energy is made available to higher trophic levels, whereas when they are lysed, organic carbon and nutrients are dissolved and bacterial carbon is recycled as bacterial production in a closed loop (Middelboe et al., 1996; Wilhelm et al., 2002). Viruses have been shown to account for a high percentage of bacterial mortality in some marine environments (Weinbauer and Peduzzi, 1995; Wells and Deming, 2006; Taira et al., 2009), with percentages similar to those due to nanoflagellates when both sources of bacterial loss have been measured simultaneously (Fuhrman and Noble, 1995; Steward et al., 1996). Therefore, it is important to estimate both virus- and grazing-induced bacterial mortality to obtain better insight into the forces underlying nutrient flow within an aquatic food web.

Most studies previously examining the impact of grazing versus viral lysis have focused on bacterial populations (Weinbauer and Peduzzi, 1995; Steward et al., 1996; Weinbauer and Höfle, 1998; Pedros-Alio et al., 2000; Jacquet et al., 2005; Fischer et al., 2006; Wells and Deming, 2006). These studies have shown that both viral lysis and grazing can cause significant mortality, but that the impact of each varies by season, host organism, and environmental conditions. The importance of viral lysis has been shown 


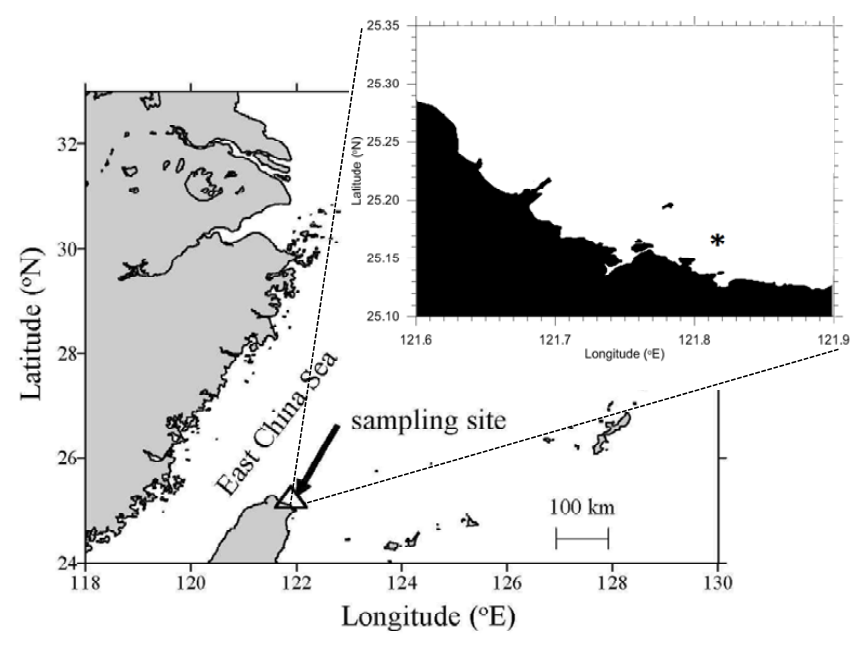

Fig. 1. Map of sampling stations.

to increase in situations where protozoan grazing is reduced (Bettarel et al., 2004). For example, Weinbauer and Höfle (1998) reported lytic mortality to be strongly dominant in the anaerobic hypolimnion layer of the lake Plussee, Germany, where protists are scarce due to oxygen depletion. Seasonally, viral lysis is reported to be the main cause of bacterial mortality during the winter, while grazing is reported to be the cause of most bacterial mortality during the spring (Wells and Deming, 2006; Tijdens et al., 2008). Furthermore, nanoflagellates have been reported to be the predominant cause of mortality and viruses a less important one in a summer study of a eutrophic bay (Choi et al., 2003). To date, studies in oligotrophic waters of subtropical western Pacific have mainly focused on bacterial mortality due to nanoflagellate grazing (Tsai et al., 2005, 2008, 2011). The contribution of viruses to bacterial mortality in this environment of subtropical western Pacific is still poorly understood.

Experimental tests of long-term seasonal variations comparing the effect of grazing with that of viral lysis on bacterial production are scarce in marine systems. Some previous studies have performed simultaneous monitoring and experiments to assess the impact of viruses and nanoflagellates on heterotrophic bacteria, cyanobacteria and phytoplankton in aquatic environments (marine or lake waters) but only for restricted periods of the year (Evans et al., 2003; Jacquet et al., 2005; Wells and Deming, 2006; Kimmance et al., 2007; Tijdens et al., 2008). Furthermore, while there have been several long-term seasonal studies to estimate grazing and viral mortality of bacteria in freshwater environments (Personnic et al., 2009), little is known about the seasonal variations of mortality impact of viral lysis and grazing on bacteria in marine ecosystems.

Until now, studies in the coastal ecosystem of subtropical western Pacific environment have mainly focused on bacterial mortality due to nanoflagellate grazing (Tsai et al., 2005, $2008,2011)$. The contribution of viruses to bacterial mortal- ity is still poorly understood. In this study, our main goals were to use the modified dilution approach to estimate grazing and viral mortality of bacteria and to compare their relative contributions of both to bacterial mortality for about $2 \mathrm{yr}$ in the coastal ecosystem of subtropical western Pacific.

\section{Material and methods}

\subsection{Sampling}

Research was conducted aboard the R/V Ocean Research II and Taiwan coastal water samples were collected monthly at the same time of day (10:00 to 11:00 LT) for about $2 \mathrm{yr}$ (Fig. 1). Seawater from $5 \mathrm{~m}$ depth was collected in a $10 \mathrm{~L}$ Niskin bottle and gently siphoned into clear, light-proof, $5 \mathrm{~L}$ polypropylene carboys. Continuous measurements of temperature and salinity were taken at the station at different levels from the surface to near bottom using a SeaBird CTDGeneral Oceanic Rosette. Nutrients of seawater samples were measured as previously described by Gong et al. (1995). Water samples were filtered ( $25 \mathrm{~mm} \mathrm{GF} / \mathrm{F})$ for Chl $a$ analysis and measured after extraction with an in vitro fluorometer (Turner Design 10-AU-005) (Parsons et al., 1984). Primary productivity of surface water $(5 \mathrm{~m})$ was measured by ${ }^{14} \mathrm{C}$ assimilation (Parsons et al., 1984).

\subsection{Dilution experiments}

We estimated viral lysis and nanoflagellate grazing rates using a modified technique involving parallel dilution experiments - a "standard" set that reduces grazers and a set that reduces both grazers and viruses (Evans et al., 2003). Filter holders and incubation bottles were acid-cleaned with $10 \%$ $\mathrm{HCl}$ and rigorously rinsed with Milli-Q water. To prepare the "standard" diluents, the natural sample was passed through $10 \mu \mathrm{m}$ mesh and then filtered through a $47 \mathrm{~mm}$ Nuclepore filter (type PC, pore size of $0.2 \mu \mathrm{m}$ ). The filtered seawater sample $(<10 \mu \mathrm{m})$ was then diluted with the $0.2 \mu \mathrm{m}$ filtered seawater in a 4-point dilution series: $25,50,75$, and $100 \%$ seawater $(<10 \mu \mathrm{m})$. The mixtures were incubated for $12 \mathrm{~h}$ in triplicate in $50 \mathrm{ml}$ polycarbonate bottles under natural light in a water bath set at the same temperature as the seawater at the time of sampling. The size fractionation used for grazers $(<10 \mu \mathrm{m})$ was chosen based on previous studies at this site to eliminate ciliates but not nanoflagellates (Tsai et al., 2011). An additional dilution series, which used $30 \mathrm{kDa}$ filtered seawater instead of $0.2 \mu \mathrm{m}$ filtered water, was used to modify both grazing and viral mortalities. The net growth rate of bacteria $\left(\mathrm{k}, \mathrm{h}^{-1}\right)$ was calculated for each sample based on microscopic cell counts at the start and the end of the experiment $\left(\mathrm{N}_{t}\right.$ and $\mathrm{N}_{t 0}$ ), assuming exponential growth (Landry and Hassett, 1982):

$k=\ln \left(\mathrm{N}_{t} / \mathrm{N}_{t 0}\right) /\left(t-t_{0}\right)$. 
The regression coefficient of apparent growth rate versus dilution factor for the $0.2 \mu \mathrm{m}$ dilution series, though usually interpreted as protistan grazing (mg) (Landry and Hassett, 1982), actually includes viral mortality (mv), since most viruses pass through a $0.2 \mu \mathrm{m}$ pore (Evans et al., 2003). However, when virus-free seawater ( $30 \mathrm{kDa}$ filters) is used as a diluent, the regression reflects release from both grazing and viral mortality $(\mathrm{mg}+\mathrm{mv})$, and a direct estimate of viral mortality for bacteria can be obtained from the difference in slopes of the regression lines between the two dilution series.

A carbon budget was determined by combining the cellular carbon content estimates and data from the modified dilution experiments. Carbon content for heterotrophic bacteria was based on values reported in Caron et al. (1995) $\left(15 \mathrm{fg} \mathrm{C}\right.$ cell $\left.^{-1}\right)$. For bacteria in this study, carbon production ( $\mathrm{BP}$ in $\mu \mathrm{g} \mathrm{CL}^{-1} \mathrm{~d}^{-1}$ ), losses due to grazing ( $\mathrm{G}$, $\left.\mu \mathrm{gCL} \mathrm{CL}^{-1} \mathrm{~d}^{-1}\right)$, and viral lysis $\left(\mathrm{V}, \mu \mathrm{gCL^{-1 }} \mathrm{d}^{-1}\right)$ were calculated using the following formulae: $\mathrm{BP}=\mu \times \mathrm{B}_{0}$, $\mathrm{G}=\mathrm{mg} \times \mathrm{B}_{0}$ and $\mathrm{V}=\mathrm{mv} \times \mathrm{B}_{0}$, where $\mu$ is the dilutionbased specific growth (y-intercept of the $30 \mathrm{kDa}$ regression), $\mathrm{mg}$ and $\mathrm{mv}$ are the dilution-based grazing and viral lysis rates, and $\mathrm{B}_{0}$ is the heterotrophic bacterial biomass ( $\mu \mathrm{g}$ $\mathrm{C} \mathrm{L}^{-1}$ ) at the sampling time.

\subsection{Viral, bacterial, Synechococcus spp. and nanoflagellate abundance counts}

Viruses, bacteria, Synechococcus spp. and nanoflagellates were counted using an epifluorescence microscope (Nikon Optiphot-2) $(1000 \times)$. Viruses were processed using a slight modification of a protocol described by Nobel and Fuhrman (1998). Briefly, samples from 0.5 to $1 \mathrm{~mL}$ were filtered on Anodisc filter $(0.02 \mu \mathrm{m}$ pore size, Whatman) backed by $0.45 \mu \mathrm{m}$ pore size Millipore filter. The samples were then placed on drops of SYBR Green I (Molecular Probes) solution diluted at $1: 400$ in TE buffer $(10 \mathrm{mM}$ Tris- $\mathrm{HCl}, 1 \mathrm{mM}$ EDTA, pH 8.0) and stained for $15 \mathrm{~min}$ in the dark. The membranes were placed on glass slides and added with $25 \mu \mathrm{L}$ of $50 \%$ glycerol $/ 50 \%$ PBS buffer $(0.85 \% \mathrm{NaCl}, 0.05 \mathrm{M}$ $\mathrm{NaH}_{2} \mathrm{PO}_{4}, \mathrm{pH} 7.5$ ) containing $0.1 \% p$-phenylenediamine as antifade and mounting agents. Subsamples of $1-2 \mathrm{~mL}$ or $20 \mathrm{~mL}$ were filtered onto $0.2 \mu \mathrm{m}$ or $0.8 \mu \mathrm{m}$ black Nuclepore filters for picoplankton (bacteria and Synechococcus spp.) and nanoflagellates, respectively. Samples were stained with DAPI at a final concentration of $1 \mu \mathrm{g} \mathrm{mL}^{-1}$ (Porter and Feig, 1980) to count bacteria and heterotrophic nanoflagellates (HNFs). Pigmented nanoflagellates (PNFs) and HNFs were counted based on the absence or presence of chlorophyll autofluorescence using a separate filter set optimized for chlorophyll or DAPI under a $1000 \times$ epifluorescence microscope (Nikon Optiphot-2). Bacteria and HNFs were identified by their blue fluorescence under UV illumination. PNFs and Synechococcus spp. were identified by their red and orange autofluorescence under blue excitation light. To obtain reliable estimates of abundance, we counted $30,30,30$ and 50 fields of view for viruses, bacteria, Synechococcus spp. and nanoflagellates, respectively.

\subsection{Statistical analysis}

Least-squares regression analysis was performed to analyze the relationship between bacterial growth rate and fraction of $30 \mathrm{kDa}$ or $0.2 \mu \mathrm{m}$ dilution series. Significance of the regression lines was tested using an analysis of variance (ANOVA). Moreover, the significance between the slopes of the $30 \mathrm{kDa}$ and $0.2 \mu \mathrm{m}$ dilution series was determined using an $F$ test. If the regression slopes of $30 \mathrm{kDa}$ and $0.2 \mu \mathrm{m}$ dilution series were significantly different, we calculated the magnitude of viral mortality. STATISTICA 7.0 software was used for all statistical operations. A probability value of $<0.05$ was considered significant.

\section{Results}

\subsection{Physical, chemical and biological characterization of the study area}

Surface water temperatures during the study showed strong seasonality with maximum values recorded during the summer period $\left(32^{\circ} \mathrm{CC}\right.$ in June 2012$)$ and minimum values during winter $\left(18.4{ }^{\circ} \mathrm{C}\right.$ in December 2011) (Table 1). Chlorophyll $a$ concentrations and primary productivity also showed distinct seasonal patterns with highest values recorded in summer $\left(2.41 \mathrm{mg} \mathrm{m}^{-3}\right.$ and $320.72 \mathrm{mgC} \mathrm{m}^{-3} \mathrm{~d}^{-1}$ in July 2011) and lowest in cold season $\left(<20^{\circ} \mathrm{C}, 0.31 \mathrm{mg} \mathrm{m}^{-3}\right.$ in April and $6.29 \mathrm{mgC} \mathrm{m}^{-3} \mathrm{~d}^{-1}$ in December 2011) (Table 1).

The results of the seasonal variations in bacterial, Synechococcus spp. and viral abundance are shown in Fig. 2a. Abundance of bacteria and Synechococcus spp. during the study period ranged from $4.1 \times 10^{5}$ to $8.6 \times 10^{5}{\text { cells } \mathrm{mL}^{-1}}^{-1}$ and $0.6 \times 10^{4}$ to $5.1 \times 10^{4}$ cells $\mathrm{mL}^{-1}$, respectively (Fig. $2 \mathrm{a}$ ). Furthermore, viral abundance was found to range from 2.1 to $9.2 \times 10^{6}$ viruses $\mathrm{mL}^{-1}$ and was found to demonstrate a clear pattern in seasonal variability at this study site (Fig. 2a). Seasonal variations of PNF abundance were similar to that of HNF throughout the study period, though HNF abundance was lower than PNF in the summer (Fig. 2b).

According to our data, viral abundance increased with increasing bacteria numbers and $\mathrm{Chl} a$ concentrations, exhibiting a significant relationship among them $(r=0.75$, $p<0.05 ; r=0.41, p<0.05$ ) (Fig. 3a, b). Furthermore, the relationship between Synechococcus spp. and viral abundance was also significant in our direct counts $(r=0.53$, $p<0.05$ ) (Fig. 3c). 

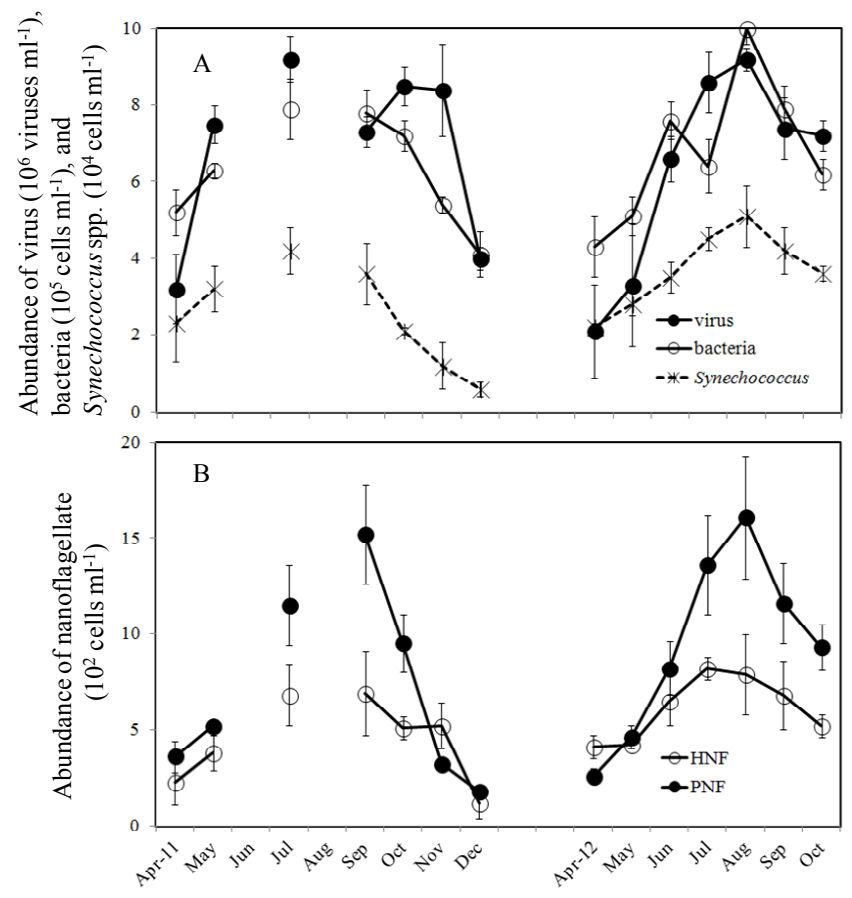

Fig. 2. (A) Seasonal variations of bacterial $\left(10^{5}\right.$ cells $\left.\mathrm{mL}^{-1}\right)$, viral $\left(10^{6}\right.$ viruses $\left.\mathrm{mL}^{-1}\right)$ and Synechococcus spp. abundance $\left(10^{4}\right.$ cells $\left.\mathrm{mL}^{-1}\right)$ and (B) heterotrophic nanoflagellate (HNF) $\left(10^{2}\right.$ cells $\left.\mathrm{mL}^{-1}\right)$ and pigmented nanoflagellate (PNF) $\left(10^{2}\right.$ cells $\left.\mathrm{mL}^{-1}\right)$ of surface water $(5 \mathrm{~m})$ during the study period.

\subsection{Dilution experiments and bacterial growth and mortality}

We used a modified dilution method to estimate rates of bacterial growth $(\mu)$, grazing $(\mathrm{mg})$ and viral lysis $(\mathrm{mv})$ from April to December 2011 and April to October 2012 (Table 1). Regression analysis was applied to the dilution experiments, which allowed us to determine both the growth and mortality coefficient in each of parallel dilution series (Table 1). For 26 of the 28 experiments, there was a significant relationship $(p<0.05)$ between bacterial growth rate and the level of dilution in both the $0.2 \mu \mathrm{m}$ and $30 \mathrm{kDa}$ series (Table 1). However, there was no significant difference ( $F$ test, $p>0.05$ ) between the regression slopes of growth rate and level of dilution of the $0.2 \mu \mathrm{m}$ and $30 \mathrm{kDa}$ series in June, July and August 2012 experiment (Table 1). For this situation, an estimate of viral mortality of bacteria at a level of significance of $p<0.05$ could not be determined for this experiment (Table 2).

The y-intercepts of these regression lines for $30 \mathrm{kDa}$ series represent the growth rates of bacteria in the absence of lytic and grazing pressure. They ranged from $0.078 \mathrm{~h}^{-1}$ (April 2011) to $0.42 \mathrm{~h}^{-1}$ (September 2011) (Table 2). Moreover, our study shows that temperature can play an important role in controlling bacterial growth, as we found there to be positive relationships between the growth rates and tem-
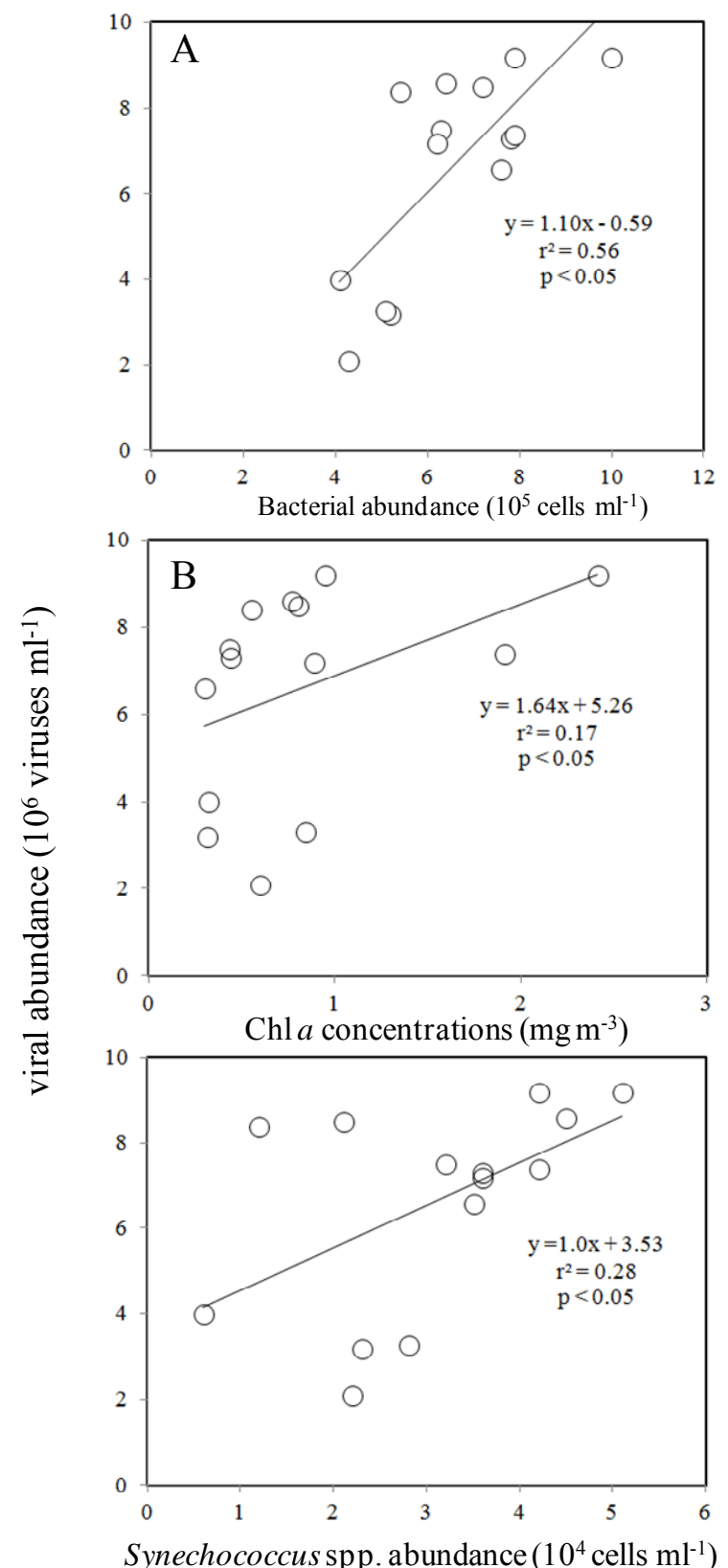

Fig. 3. Relationships between viral and bacterial (A), Chl $a$ concentrations (B) and Synechococcus spp. abundance (C).

perature (growth rate $\left(\mathrm{h}^{-1}\right)=0.019$ temp. $-0.29, r^{2}=0.43$, $p<0.05$ ) (Fig. 4a), and this to be a better degree of explanation than Chl $a$ (Fig. 4b). Furthermore, the regression coefficients (slopes) for $0.2 \mu \mathrm{m}$ fractionated series, which represent bacterial grazing mortality $(\mathrm{mg})$, ranged from 0.033 to $0.18 \mathrm{~h}^{-1}$ (Table 2). We found seasonal variation in viral lysis rates, with slope differences between $0.2 \mu \mathrm{m}$ and $30 \mathrm{kDa}$ series ranging from $0.038 \mathrm{~h}^{-1}$ to $0.300 \mathrm{~h}^{-1}$ during the study period (Table 2). 
Table 1. Environmental factors (temperature, chlorophyll $a$ and primary production) and results from the parallel dilution experiments. The significance $(p)$ of the regression analyses (ANOVA) and the significance between the slopes of the regression of $0.2 \mu \mathrm{m}$ and $30 \mathrm{kDa}$ dilution series determined using an $F$ test are shown. ND: no data. A probability value of $<0.05$ was considered significant in bold value

\begin{tabular}{|c|c|c|c|c|c|c|c|}
\hline 2011 & $\begin{array}{r}\text { Temperature } \\
\left({ }^{\circ} \mathrm{C}\right)\end{array}$ & $\begin{array}{r}\text { Chl } a \\
\left(\mathrm{mg} \mathrm{m}^{-3}\right)\end{array}$ & $\begin{array}{r}\text { Primary } \\
\text { production } \\
\left(\mathrm{mg} \mathrm{C} \mathrm{m}^{-3} \mathrm{~d}^{-1}\right)\end{array}$ & Diluent & $\begin{array}{r}\text { Regression } \\
\text { equation }\end{array}$ & $\begin{array}{r}\text { Regression } \\
(p)\end{array}$ & $\begin{array}{r}\text { Difference of } \\
\text { regression slopes } \\
(p)\end{array}$ \\
\hline Apr & 19.7 & 0.31 & 50.28 & $\begin{array}{l}0.2 \mu \mathrm{m} \\
30 \mathrm{kDa}\end{array}$ & $\begin{array}{l}y=-0.037 x+0.045 \\
y=-0.075 x+0.078\end{array}$ & $\begin{array}{l}<0.05 \\
<0.01\end{array}$ & $<\mathbf{0 . 0 1}$ \\
\hline May & 21.1 & 0.43 & 14.84 & $\begin{array}{c}0.2 \mu \mathrm{m} \\
30 \mathrm{kDa}\end{array}$ & $\begin{array}{l}y=-0.039 x+0.052 \\
y=-0.079 x+0.083\end{array}$ & $\begin{array}{l}<0.01 \\
<0.01\end{array}$ & $<\mathbf{0 . 0 5}$ \\
\hline Jun & ND & ND & $\begin{array}{r}\text { ND } \\
30 \mathrm{kDa}\end{array}$ & $\begin{array}{r}0.2 \mu \mathrm{m} \\
\mathrm{ND}\end{array}$ & ND & & \\
\hline Jul & 27.5 & 2.41 & 320.72 & $\begin{array}{l}0.2 \mu \mathrm{m} \\
30 \mathrm{kDa}\end{array}$ & $\begin{array}{r}y=-0.148 x+0.094 \\
y=-0.195 x+0.36\end{array}$ & $\begin{array}{l}<0.01 \\
<0.01\end{array}$ & $<\mathbf{0 . 0 5}$ \\
\hline Aug & ND & ND & ND & $\begin{array}{l}0.2 \mu \mathrm{m} \\
30 \mathrm{kDa}\end{array}$ & $\begin{array}{r}\text { ND } \\
\text { ND }\end{array}$ & & \\
\hline Sep & 28.1 & 0.44 & 53.20 & $\begin{array}{l}0.2 \mu \mathrm{m} \\
30 \mathrm{kDa}\end{array}$ & $\begin{array}{r}y=-0.142 x+0.084 \\
y=-0.445 x+0.42\end{array}$ & $\begin{array}{l}<0.01 \\
<0.01\end{array}$ & $<\mathbf{0 . 0 1}$ \\
\hline Oct & 25.3 & 0.8 & 12.26 & $\begin{array}{l}0.2 \mu \mathrm{m} \\
30 \mathrm{kDa}\end{array}$ & $\begin{array}{l}y=-0.18 x+0.093 \\
y=-0.325 x+0.27\end{array}$ & $\begin{array}{l}<0.01 \\
<0.01\end{array}$ & $<\mathbf{0 . 0 5}$ \\
\hline Nov & 21 & 0.55 & 18.42 & $\begin{array}{l}0.2 \mu \mathrm{m} \\
30 \mathrm{kDa}\end{array}$ & $\begin{array}{r}y=-0.099 \mathrm{x}+0.046 \\
y=-0.2 \mathrm{x}+0.17\end{array}$ & $\begin{array}{l}<\mathbf{0 . 0 1} \\
<\mathbf{0 . 0 1}\end{array}$ & $<0.01$ \\
\hline Dec & 18.4 & 0.32 & 6.29 & $\begin{array}{l}0.2 \mu \mathrm{m} \\
30 \mathrm{kDa}\end{array}$ & $\begin{array}{l}y=-0.033 x+0.038 \\
y=-0.157 x+0.146\end{array}$ & $\begin{array}{l}<0.05 \\
<0.05\end{array}$ & $<\mathbf{0 . 0 1}$ \\
\hline 2012 & & & & & & & \\
\hline Apr & 24.5 & 0.60 & ND & $\begin{array}{l}0.2 \mu \mathrm{m} \\
30 \mathrm{kDa}\end{array}$ & $\begin{array}{l}y=-0.045 x+0.052 \\
y=-0.096 x+0.095\end{array}$ & $\begin{array}{l}<0.01 \\
<\mathbf{0 . 0 5}\end{array}$ & $<\mathbf{0 . 0 1}$ \\
\hline May & 25.4 & 0.84 & ND & $\begin{array}{l}0.2 \mu \mathrm{m} \\
30 \mathrm{kDa}\end{array}$ & $\begin{array}{l}y=-0.043 x+0.055 \\
y=-0.131 x+0.158\end{array}$ & $\begin{array}{r}0.064 \\
<\mathbf{0 . 0 1}\end{array}$ & $<\mathbf{0 . 0 5}$ \\
\hline Jun & 32 & 0.51 & ND & $\begin{array}{l}0.2 \mu \mathrm{m} \\
30 \mathrm{kDa}\end{array}$ & $\begin{array}{l}y=-0.12 x+0.23 \\
y=-0.16 x+0.28\end{array}$ & $\begin{array}{l}<0.05 \\
<0.05\end{array}$ & 0.326 \\
\hline Jul & 28.5 & 0.77 & ND & $\begin{array}{l}0.2 \mu \mathrm{m} \\
30 \mathrm{kDa}\end{array}$ & $\begin{array}{l}y=-0.082 x+0.048 \\
y=-0.106 x+0.121\end{array}$ & $\begin{array}{l}<\mathbf{0 . 0 1} \\
<\mathbf{0 . 0 1}\end{array}$ & 0.298 \\
\hline Aug & 26.6 & 0.95 & ND & $\begin{array}{l}0.2 \mu \mathrm{m} \\
30 \mathrm{kDa}\end{array}$ & $\begin{array}{l}y=-0.05 x+0.038 \\
y=-0.092 x+0.15\end{array}$ & $\begin{array}{l}<\mathbf{0 . 0 1} \\
<\mathbf{0 . 0 1}\end{array}$ & 0.18 \\
\hline Sep & 27.9 & 1.91 & ND & $\begin{array}{l}0.2 \mu \mathrm{m} \\
30 \mathrm{kDa}\end{array}$ & $\begin{array}{r}y=-0.08 x+0.24 \\
y=-0.18+0.31\end{array}$ & $\begin{array}{r}0.063 \\
<\mathbf{0 . 0 5}\end{array}$ & $<\mathbf{0 . 0 5}$ \\
\hline Oct & 23.5 & 0.89 & ND & $\begin{array}{l}0.2 \mu \mathrm{m} \\
30 \mathrm{kDa}\end{array}$ & $\begin{array}{l}y=-0.05 x-0.071 \\
y=-0.142+0.127\end{array}$ & $\begin{array}{l}<0.05 \\
<0.05\end{array}$ & $<\mathbf{0 . 0 5}$ \\
\hline
\end{tabular}

Our results also showed that the carbon losses due to viral lysis and nanoflagellate grazing were 7.34-88.56 $\mu \mathrm{g} \mathrm{C} \mathrm{L}^{-1} \mathrm{~d}^{-1}$ and 6.42-48.60 $\mu \mathrm{g} \mathrm{CL}^{-1} \mathrm{~d}^{-1}$, respectively (Table 2). It appeared that nanoflagellate grazing and viral lysis could account for $33.3 \%$ to $66.7 \%$ and $13.1 \%$ to $137.8 \%$ of the daily removal of bacterial production, respectively (Fig. 5). The impact of viruses on bacterial mortality had not been measured between June and August 2012 (Fig. 5).

\section{Discussions}

The present study explored seasonal variations in bacterial mortality caused by grazing and viruses in the coastal ecosystem of subtropical western Pacific. The ratios of total mortality generated by nanoflagellate grazing were found to be generally higher in summer periods (July 2011), especially between June and August 2012, when no significant viral lysis rates were recorded. However, viral lysis was found to be the main cause of bacterial mortality between September and December, when it removed between $53 \%$ and $137 \%$ of the potential bacterial production (Fig. 5).

Previous work in the same region, which used sizefractionation approach with $2 \mu \mathrm{m}$ filters, reported the average 
Table 2. Dilution-based specific growth rates in $30 \mathrm{kDa}$ experiments $(\mu)$, nanoflagellate grazing (mg) and viral lysis rates (mv) for the heterotrophic bacteria. Daily bacterial carbon production (BP) and the fraction of carbon losses by nanoflagellate grazing (G), viruses (V) and the ratios of nanoflagellate grazing $(\mathrm{mg})$ to total mortality of bacteria $(\mathrm{mg}+\mathrm{mv})$ were calculated for each experiment. sd: standard deviations. ND: no data, -: grazing or viral lysis estimates were not statistically significant $(p>0.05)$.

\begin{tabular}{|c|c|c|c|c|c|c|c|}
\hline 2011 & $\begin{array}{l}\mu(30 \mathrm{kDa}) \pm \mathrm{sd} \\
\left(\mathrm{h}^{-1}\right)\end{array}$ & $\begin{array}{l}\mathrm{mg} \pm \mathrm{sd} \\
\left(\mathrm{h}^{-1}\right)\end{array}$ & $\begin{array}{l}\mathrm{mv} \pm \mathrm{sd} \\
\left(\mathrm{h}^{-1}\right)\end{array}$ & $\begin{array}{l}\mathrm{BP} \pm \mathrm{sd} \\
\left(\mu \mathrm{g} \mathrm{C} \mathrm{L}^{-1} \mathrm{~d}^{-1}\right)\end{array}$ & $\begin{array}{l}\mathrm{G} \pm \mathrm{sd} \\
\left(\mu \mathrm{g} \mathrm{C} \mathrm{L}^{-1} \mathrm{~d}^{-1}\right)\end{array}$ & $\begin{array}{l}\mathrm{V} \pm \mathrm{sd} \\
\left(\mu \mathrm{g} \mathrm{CL}^{-1} \mathrm{~d}^{-1}\right)\end{array}$ & $\begin{array}{l}\mathrm{mg} \pm \mathrm{sd}(\%) \\
((\mathrm{mg}) /(\mathrm{mg}+\mathrm{mv}) \\
\times 100 \%)\end{array}$ \\
\hline Apr & $0.078 \pm 0.006$ & $0.037 \pm 0.008$ & $0.038 \pm 0.004$ & $16.85 \pm 0.52$ & $7.99 \pm 0.05$ & $8.21 \pm 0.005$ & $49 \pm 0.5 \%$ \\
\hline May & $0.083 \pm 0.008$ & $0.039 \pm 0.009$ & $0.040 \pm 0.003$ & $18.83 \pm 0.65$ & $8.85 \pm 0.08$ & $9.07 \pm 0.009$ & $49 \pm 0.3 \%$ \\
\hline Jun & ND & ND & ND & ND & ND & ND & ND \\
\hline Jul & $0.360 \pm 0.051$ & $0.148 \pm 0.015$ & $0.047 \pm 0.006$ & $102.38 \pm 9.11$ & $42.09 \pm 0.65$ & $13.37 \pm 0.004$ & $76 \pm 1.1 \%$ \\
\hline Aug & ND & ND & ND & ND & ND & ND & ND \\
\hline Sep & $0.420 \pm 0.015$ & $0.142 \pm 0.028$ & $0.300 \pm 0.011$ & $123.98 \pm 6.23$ & $41.92 \pm 1.12$ & $88.56 \pm 2.33$ & $32 \pm 0.6 \%$ \\
\hline Oct & $0.270 \pm 0.012$ & $0.180 \pm 0.022$ & $0.145 \pm 0.021$ & $72.90 \pm 1.33$ & $48.60 \pm 0.84$ & $39.15 \pm 0.95$ & $55 \pm 0.4 \%$ \\
\hline Nov & $0.170 \pm 0.009$ & $0.099 \pm 0.011$ & $0.101 \pm 0.009$ & $47.12 \pm 2.39$ & $27.44 \pm 0.29$ & $28.00 \pm 0.32$ & $50 \pm 0.6 \%$ \\
\hline Dec & $0.090 \pm 0.011$ & $0.033 \pm 0.006$ & $0.124 \pm 0.014$ & $17.50 \pm 0.98$ & $6.42 \pm 0.06$ & $24.11 \pm 0.41$ & $21 \pm 0.4 \%$ \\
\hline \multicolumn{8}{|l|}{2012} \\
\hline Apr & $0.095 \pm 0.012$ & $0.045 \pm 0.008$ & $0.051 \pm 0.005$ & $14.71 \pm 0.87$ & $6.97 \pm 0.09$ & $7.89 \pm 0.041$ & $47 \pm 0.6 \%$ \\
\hline May & $0.158 \pm 0.033$ & - & $0.131 \pm 0.011$ & $29.01 \pm 0.45$ & - & $7.34 \pm 0.091$ & - \\
\hline Jun & $0.280 \pm 0.098$ & $0.120 \pm 0.012$ & - & $76.61 \pm 1.06$ & $32.83 \pm 0.22$ & - & - \\
\hline Jul & $0.121 \pm 0.045$ & $0.082 \pm 0.005$ & - & $27.88 \pm 2.09$ & $18.89 \pm 0.31$ & - & - \\
\hline Aug & $0.150 \pm 0.047$ & $0.050 \pm 0.008$ & - & $54.00 \pm 3.39$ & $18.00 \pm 0.09$ & - & - \\
\hline Sep & $0.310 \pm 0.084$ & - & $0.180 \pm 0.008$ & $88.16 \pm 2.08$ & - & $38.39 \pm 0.32$ & - \\
\hline Oct & $0.127 \pm 0.092$ & $0.050 \pm 0.006$ & $0.092 \pm 0.010$ & $28.35 \pm 3.12$ & $11.16 \pm 0.06$ & $20.53 \pm 0.22$ & $35 \pm 0.7 \%$ \\
\hline
\end{tabular}

bacterial growth to be $0.046 \mathrm{~h}^{-1}$ in the summer (Tsai et al., 2008). In the current study, which followed standard protocol with $0.2 \mu \mathrm{m}$ diluents, the growth rates of bacteria ranged from 0.084 to $0.094 \mathrm{~h}^{-1}$ in the summer periods (June-October) (Table 1), about 2-fold greater than previously reported by Tsai et al. (2008). Both of these methods have a degree of error associated with them, because not all nanoflagellates may be eliminated using $2 \mu \mathrm{m}$ filters. About $12 \%$ of nanoflagellates pass through a $2 \mu \mathrm{m}$ filter in the size-fractionation approach (Tsai et al., 2008). This situation could have caused an underestimation of bacterial growth rates. Moreover, the current study observed higher bacterial growth rates in the $30 \mathrm{kDa}$ (grazer- and virus-free water) than in the $0.2 \mu \mathrm{m}$ diluents (Table 1), suggesting that under conditions in which lytic pressure was relatively high, the growth rate obtained from the standard protocol $(0.2 \mu \mathrm{m}$ series) might have been underestimated because almost all viruses could remain in the $0.2 \mu \mathrm{m}$ diluent water samples. Similar findings have been recorded (Wells and Deming, 2006; Tijden et al., 2008; Taira et al., 2009).

To understand the role of viruses in the marine environment, it is important to know the seasonal changes of viral abundance in relation to the variations of bacteria, phytoplankton and other biological parameters. We observed positive correlations between viruses and bacteria. Similar relations between viruses and bacteria have also been reported in most aquatic environments (Alonso et al., 2001; Hewson et al., 2001; Bettarel et al., 2003), where almost all of the viruses seem in fact to be bacteriophages (Wommack and Colwell, 2000). Based on a linear regression analysis in this study, variation in bacterial abundance was found to explain $56 \%$ of the variability in viral abundance and could be used as the sole predictor to explain seasonal change in virus abundance and could be a better degree of explanation than Chl $a\left(r^{2}=0.17\right)$. These results are similar to those reported by Cochlan et al. (1993), who demonstrated that bacterial abundance could be a superior predictor variable to chlorophyll $a$. In their models, bacterial abundance explained $69 \%$ of the variation in viral abundance as opposed to chlorophyll, which explained only $45 \%$. The generally poorer correlations between virus abundance and $\mathrm{Chl} a$ concentration do not discount the possibility that phytoplankton are significant hosts of the viruses at our study site. Since Chl $a$ is only a proxy for phytoplankton biomass, it may not accurately reflect phytoplankton abundance. Furthermore, previous studies on viral lysis in oligotrophic environments have focused on Synechococcus spp. (Garza and Suttle, 1998; Baudoux et al., 2007, 2008), though the present study found a poorer correlation between viruses and Synechococcus spp. abundance (Fig. 3c). The poorer correlation between viruses and Synechococcus spp. abundance might suggest that Synechococcus spp. has distinct diel changes in abundance during summer, with higher abundance at nighttime. Furthermore, viral lysis is reported to be an important cause of Synechococcus spp. mortality, especially at nighttime (Tsai et al., 2012). Viral dynamics might be controlled by external environmental 


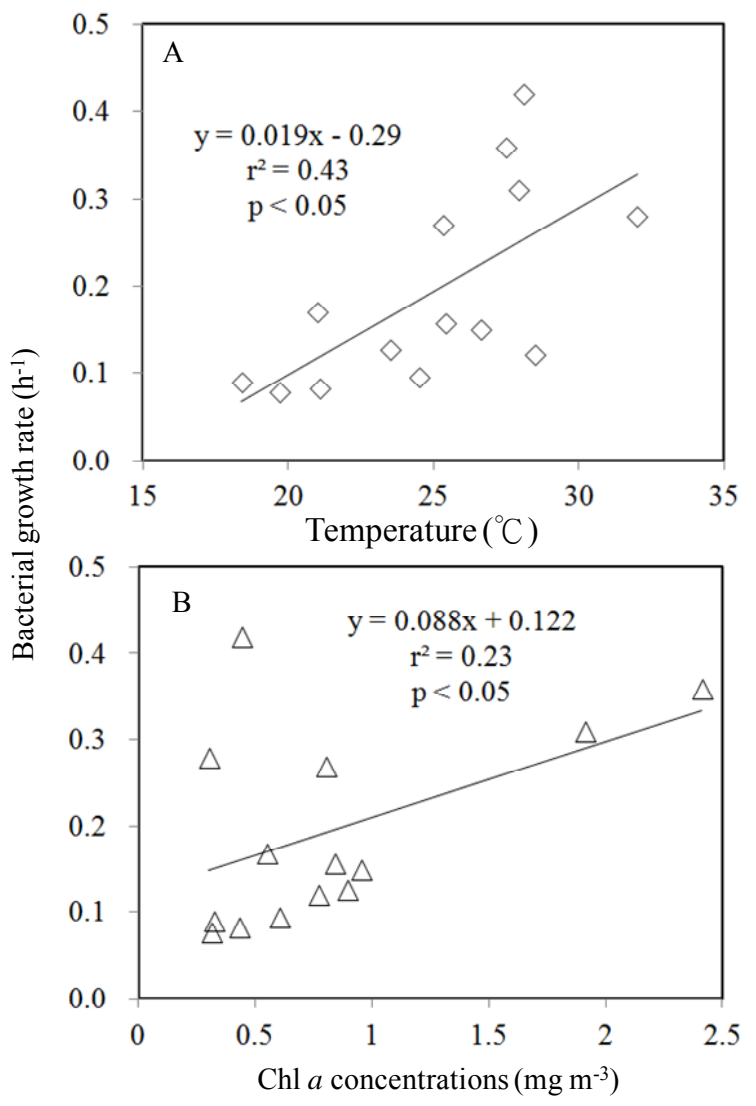

Fig. 4. Relationships between bacterial growth rates and temperature (A) and Chl $a$ concentrations (B).

factors, such as temperature and light. The fact is that no diel rhythm in viral abundance was observed in the present study; however, viral infectivity was sensitive to solar UV radiation (Suttle and Chen, 1992; Wilhelm et al., 1998; Hofer and Sommaruga, 2001). Suttle and Chen (1992) suggest that there should be a strong diel signal in the abundance of infective viruses. Temperature can also be involved in controlling the abundance of viruses as it controls bacterial growth rates and has a significant positive effect on bacterial production (Shiah and Ducklow, 1994; Tsai et al., 2008). Jiang and Paul (1994) found a positive correlation between viral abundance and temperature, as we did in the current study $(r=0.4, p<0.05)$.

The seasonal abundances of viruses and bacteria in this study were rather homeostatic as they did not vary by more than 4-fold during the study periods. This contrasts with the seasonal variation we found in the abundances of nanoflagellates, which varied by up to 6-fold for HNFs, and 10-fold for PNFs. In marine environments, it is common to have variations in the abundance of viruses between winter and summer of greater than one order of magnitude (Jiang and Paul, 1994; Weinbauer et al., 1995). One previous study showed that an increase in viral abundance is generally observed with in-

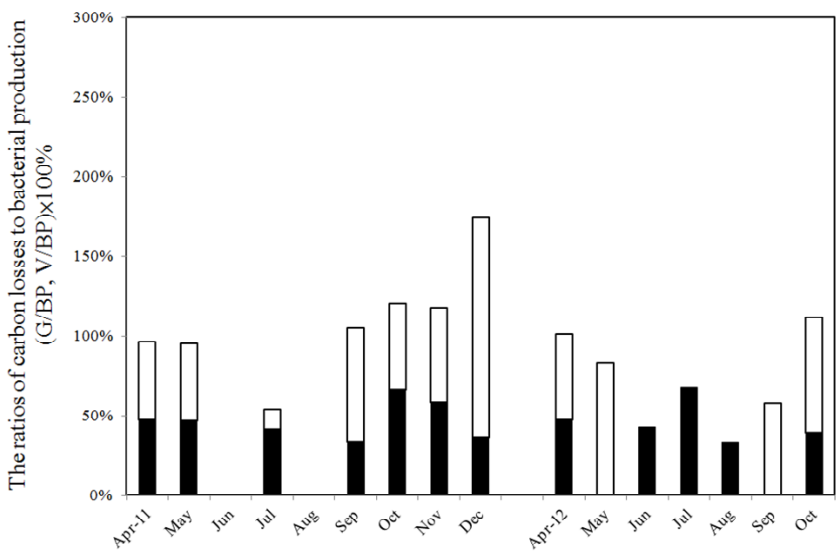

Fig. 5. Seasonal variations in the ratios of carbon losses by nanoflagellate grazing ( $\square$ ) and viral lysis $(\square)$ to bacterial production (BP) during the study period.

creasing trophic status (Wommack and Colwell, 2000). In Jiang and Paul (1994), the highest value of chlorophyll $a$ was $12.8 \mathrm{mg} \mathrm{m}^{-3}$, which was higher than the summer values $\left(0.8-2.4 \mathrm{mg} \mathrm{m}^{-3}\right)$ at our study site. Bettarel et al. (2003) also reported there to be an increasing relative abundance of such non-bacteriophage viruses as cyanophages in productive environments. This finding may explain why the seasonal abundance of viruses was significantly less varied in this study than the abundances reported in other studies. Furthermore, a particularly interesting finding in this study was that there was a more pronounced increase in abundance of PNF than in HNF during the summer period (Fig. 2b), which is similar to a study by Tsai et al. (2010), who reported that the increase in PNF caused the variation of a nanoflagellate community of the East China Sea in the summer. Similar observations have been reported in other studies (Sanders et al., 1992; Tamigneaux et al., 1995), suggesting that PNF often shows a more pronounced seasonal pattern than HNF in response to change in light and temperature. Furthermore, the interactions between viruses and grazers and their effects on picoplankton are probably very complex (Miki and Jacquet, 2008 ) and could include various antagonistic or synergistic effects (Sime-Ngando and Pradeep Ram, 2005). For example, nanoflagellates can directly reduce viral abundance and infectivity through direct consumption of viruses or by grazing preferentially on virus-infected cells (Bettarel et al., 2005). Though our study did not directly address these complexities, it does suggest that protistan grazing and viral infections interact to modify bacterial production.

To the best of our knowledge, the results of this study provide a first estimation of the potential effects of viral lysis and protozoan grazing on bacteria in this area. Several methods have been used to estimate viral mortality on components of the microbial food web. These include tracking changes in viral abundance, production and decay rate (Heldal and Bratbak, 1991; Wilhelm et al., 2002) and measuring 
the frequency of virus-infected bacterial cells (Proctor et al., 1993; Binder, 1999). These methods are based on several assumptions about latent periods and/or burst sizes for viruses. One advantage of the modified dilution method used in this study is that it provides insight into the quantitative significance of both viral lysis and grazing without the need of conversion factors (Jacquet et al., 2005). This dilution technique is now commonly applied to a wide variety of prey and environments (Weisse and Scheffel-Moeser, 1990; Worden and Binder, 2003). We also wanted to estimate mortality due viral lysis. To do this, we used the additional dilution series method (Evans et al., 2003), which has been successfully used to estimate the impact of viral lysis on the haptophyte Phaeocystis globosa (Scherffel) in temperate coastal waters (Baudoux et al., 2006) and the impact of viral lysis on bacterioplankton in freshwater and oceanic waters (Jacquet et al., 2005; Wells and Deming, 2006; Tijdens et al., 2008; Taira et al., 2009).

Generally, heterotrophic bacterial abundance and productivity in aquatic environments may be linearly dependent on phytoplankton biomass and productivity (Gasol et al., 1998). In many oligotrophic waters, there is a close association between heterotrophic bacterial and phytoplankton production (Gasol and Duarte, 2000; Duarte and Agustí, 2005), indicating that primary production ultimately provides most of the carbon needed for heterotrophic bacterial production in these settings. However, as shown in Fig. 6, this study found a significant relationship between bacterial production (BP) and released dissolved organic carbon by lysis $(\mathrm{V})$, but no significant relationship between BP and primary production $(p=0.1)$. This observation suggests that viral infection is an important mechanism in $\mathrm{C}$ recycling in the sea. If carbon released due to virus-induced lysis is converted to new bacterial cells with an efficiency of $31 \%$ (Kristiansen et al., 1992), the fraction of BP potentially sustained by viral lysates was on average only $19 \%$ (ranged from $4 \%$ to $43 \%$ ). Although virus-mediated lysis of bacteria did not contribute quantitatively to bacterial nutrition, the released material could be qualitatively important to nutrient regeneration, because cell components released by virus-mediated lysis are rich in organic nitrogen and phosphorus, can be highly labile, and are utilizable for growth by non-infected bacteria (Middleboe et al., 1996; Noble and Fuhrman, 2000). Culture studies by Middleboe et al. (1996) demonstrate a tight coupling between phosphorus released by viral lysis of bacteria and bacterial growth. In fact, viruses cause the death of their host cells (Fuhrman and Noble, 1995; Steward et al., 1996), and this viral activity produces dissolved organic carbon from lysis of particles and thereby promotes the recycling of carbon by bacteria in the water column (Nobel et al., 1999; Middelboe and Lyck, 2002). These results suggest that viral lysis of bacteria can result in both a sudden and large release of dissolved organic carbon and a rapid increase in bacterial growth rates and production.

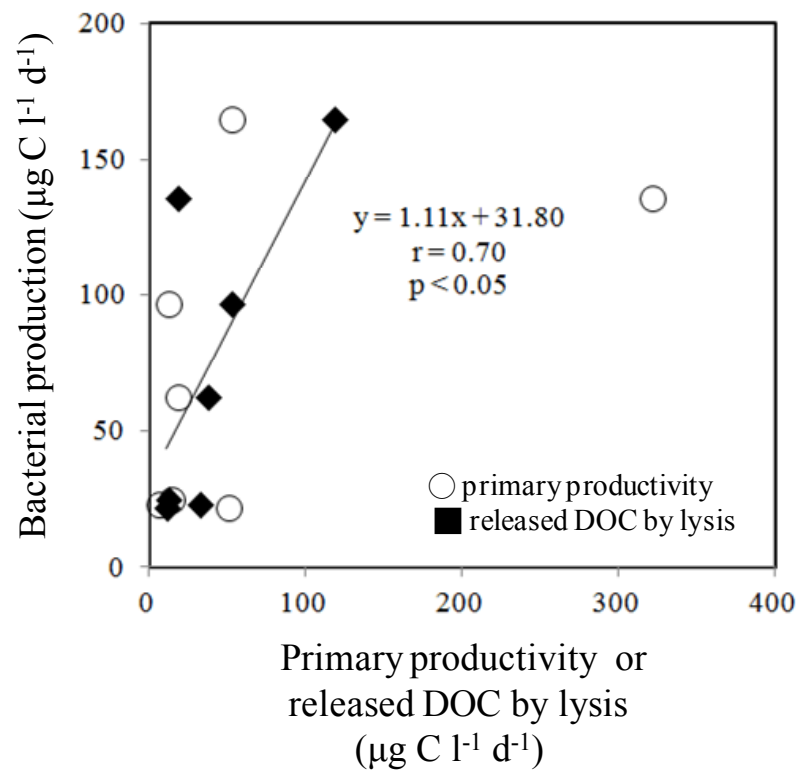

Fig. 6. Relationship between bacterial growth rates and primary production and released organic carbon (DOC) by viral lysis on bacteria (V) in 2011.

Large seasonal variations in microbial mortality have been recorded in other environments (Domaizon et al., 2003; Ortmann et al., 2011). Based on the dilution experiments in the current study, the ratio of seasonal variations of grazing effect $(\mathrm{mg})$ to these two sources of bacterial mortality $(\mathrm{mg}+\mathrm{mv})$ changed from 21 to $76 \%$ (Table 2). The ratios of nanoflagellate grazing were generally higher in summer periods (July 2011), especially between June and August 2012, with no significant viral lysis rates recorded during these periods (Table 2). We suggest that nanoflagellate grazing could play a key role in controlling bacterial biomass and might exceed the impact of viral lysis during summer period. Personnic et al. (2009) determined that nanoflagellate grazing was a significant cause of mortality in heterotrophic bacteria in the autumn (up to $42 \%$ ) and summer (up to $76 \%$ ), but in the winter and early spring, which are periods of relatively low productivity, neither the impact of the viruses nor that of the nanoflagellates could be clearly detected. The distinction and quantification of bacterial losses due to lysis and nanoflagellate grazing is essential for an optimal understanding of the carbon pathway in marine environments. Nanoflagellate grazing will mostly channel bacterial biomass to higher trophic levels in the microbial food web. Through cell lysis, bacterial biomass is converted to dissolved organic carbon, hence forcing the food web towards a more regenerative pathway (Wilhelm and Suttle, 1999). Our results substantiate earlier studies suggesting that nanoflagellates play an important role in bacterial carbon transfer to higher levels of the food web at this study site during summer (Tsai et al., 2011). However, bacterial production was not balanced 
by nanoflagellate grazing and viral lysis between June and August (33-68\% of bacterial production) (Fig. 5); therefore, other sources of bacterial losses, including cell death and sedimentation (Pace, 1988), may account for the imbalance. Steward et al. (1996) also reported comparable rates of bacterial mortality due to viral lysis and nanoflagellate bacterivory in Arctic water. They did not find a balance between bacterial production and these two sources of bacterial mortality, suggesting that other sources of bacterial mortality were present. Šimek et al. (1990) observed that ciliates contributed an average of $71 \%$ to the protozoan bacterivory and balanced bacterial production in the summer period. Previous estimates of clearance rates of bacteria have been on the order of $10^{-3} \mu \mathrm{Lcell}^{-1} \mathrm{~h}^{-1}$ for $<5 \mu \mathrm{m}$ nanoflagellates and $10^{-2} \mu \mathrm{L} \mathrm{cell}^{-1} \mathrm{~h}^{-1}$ for ciliates (Sherr et al., 1989), However, ciliate numbers are so low $\left(\sim 1\right.$ cell mL$\left.^{-1}\right)$ (Chen, 2003), thus resulting in ciliate grazing much lower than nanoflagellate grazing throughout observation period. Furthermore, Tsai et al. (2011) also reported that the grazing impact by PNF was 20 times higher than that of ciliates at our study site during summer. Thus, the potential effect of nanoflagellate predation on the removal of picoplankton in our study appears to be substantial. Moreover, our results do not negate the possibility of rotifers, cladocerans and tunicates having dominated bacterivory (Thouvenot et al., 1999; Sommer and Stibor, 2002; Work et al., 2005). Some attention has been given to the role of large-sized mesozooplankton groups feeding on bacteria and their protest predators (e.g., appendicularian tunicates). Appendicularians may play an important role in channeling carbon from bacteria and small-sized phytoplankton into higher trophic levels (Fortier et al., 1994; Vargas and González, 2004). Another possible explanation could be an underestimation of viral lysis. It has been suggested that bacterivores ingest infected bacteria, even at a higher rate than non-infected bacteria (Weinbauer and Peduzzi, 1995).

In fact, seasonal cycles of bacterial abundances are a reflection of the changing net growth rates (growth rate and loss rates). As shown in Fig. 5, total loss rates accounted for $33-68 \%$ of bacterial production (positive net growth rates) occurring from June to August. During this period, the abundance of bacteria the next month sharply increased. The total loss rate (grazing + viral lysis) gradually increased, accounting for $105-174 \%$ of bacterial production between September and December. During this period, temperature dropped after September, the net growth rates were negative, and bacterial abundance declined (Fig. 2a). Based on these findings, the observed seasonal variations in bacterial abundance can be explained by a scenario in which both growth rates and loss rates (grazing + viral lysis) influence the dynamics of the bacteria community. With regard to seasonal changes of viral lysis on bacterial mortality, viral lysis was identified as the main cause of bacterial mortality between September and December, when it clearly removed between $53 \%$ and $137 \%$ of the potential bacterial production (Fig. 5). These results imply that the carbon and nutrients released upon viral lysis of bacteria were recycled within the microbial loop (Noble and Fuhrman, 2000). The role of viral lysis and nanoflagellate grazing in bacterial mortality may change spatially and temporally. The importance of viral lysis has been shown to increase in situations where nanoflagellate grazing is reduced (Bettarel et al., 2004). Furthermore, the loss of bacterial biomass was caused by viral lysis in the cold seasons (September to December) of this study, possibly due to UV inactivation of viruses in the surface water samples in the summer (Suttle and Chen, 1992; Wilhelm et al., 1998; Hofer and Sommaruga, 2001).

\section{Conclusions}

Results from the present study reveal that a modified dilution approach can be adapted to directly determine virus-induced mortality rates of bacteria in the coastal ecosystem of subtropical western Pacific. In this study, the ratios of nanoflagellate grazing were generally higher in summer periods. We conclude that grazing transfers production from picoplankton to higher trophic levels, rather than shunting it into the dissolved pool through viral lysis, and that viral lysis was the main cause of bacterial mortality between September and December, when it removed between $53 \%$ and $137 \%$ of the potential bacterial production. Further studies are recommended to assess the wider applications of the dilution protocol developed in this study for diel variations.

Acknowledgements. This study was supported by a grant (NSC 100-2611-M-019-009) from the National Science Council, ROC. We are most grateful to James Steed for his language editing and comments on the manuscript.

Edited by: T. Kobari

\section{References}

Alonso, M. C., Jimenez-Gomez, F., Rodriguez, J., and Boorego, J. J.: Distribution of virus-like particles in an oligotrophic marine environment (Alboran sea, Western Mediterranean), Microb. Ecol., 42, 407-415, 2001.

Baudoux, A. C., Noordeloos, A. A. M., Veldhuis, M. J. W., and Brussaard, C. P. D.: Virally induced mortality of Phaeocystis globosa during two spring blooms in temperate coastal waters, Aquat. Microb. Ecol., 44, 207-217, 2006.

Baudoux, A. C., Veldhuis, M. J. W., Witte, H. J., and Brussaard, C. P. D.: Viruses as mortality agents of picophytoplankton in the deep chlorophyll maximum layer during IRONAGES III, Limnol. Oceanogr., 52, 2219-2529, 2007.

Baudoux, A. C., Veldhuis, M. J. W., Noordeloos, A. A. M., van Noor, G., and Brussaard, C. P. D.: Estimates of virus- vs. grazing induced mortality of picophytoplankton in the North Sea during summer, Aquat. Microb. Ecol., 52, 69-82, 2008. 
Bettarel, Y., Sime-Ngando, T., Amblard, C., Carrias, J. F., and Portelli, C.: Virioplankton and microbial communities in aquatic systems: a seasonal study in two lakes of differing trophy, Freshw. Biol., 48, 810-822, 2003.

Bettarel, Y., Sime-Ngando, T., Amblard, C., and Dolan, J.: Viral activity in two contrasting lake ecosystems, Appl. Environ. Microbiol., 70, 2941-2951, 2004.

Bettarel, Y., Sime-Ngando, T., Bouey, M., Arfi, R., and Amblard, C.: Low consumption of virus-sized particles by heterotrophic nanoflagellates in two lakes of French Massif Contral, Aquat. Microb. Ecol., 39, 205-209, 2005.

Binder, B.: Reconsidering the relationship between virally induced bacterial mortality and frequency of infected cells, Aquat. Microb. Ecol., 18, 207-215, 1999.

Caron, D. A., Dam, H. G., Kremer, P., Lessard, E. J., Madin, L. P., Malone, T. C., Napp, J. M., Peele, E. R., Roman, M. R., and Youngbluth, M. J.: The contribution of microorganisms to particulate carbon and nitrogen in surface waters of the Sargasso Sea near Bermuda, Deep-Sea Res., 42, 943-972, 1995.

Chen, K. M.: Ciliate grazing on Synechococcus in a coastal and shelf marine ecosystem: spatial-temporal variations and importance to biological carbon cycling, PhD dissertation, National Taiwan Ocean University, Keelung, 2003.

Choi, D. H., Hwang, C. Y., and Cho, B. C.: Comparison of virusand bacterivory-induced bacterial mortality in the eutrophic Masan Bay, Korea, Aquat. Microb. Ecol., 30, 117-125, 2003.

Cochlan, W. P., Wikner, J., Stewart, G. F., Smith, D. C., and Azam, F.: Spatial distribution of viruses, bacteria and chlorophyll a in neritic, oceanic and estuarine environments, Mar. Ecol. Prog. Ser., 82, 151-162, 1993.

Domaizon, I., Vibound, S., and Fontvieille, D. Taxon-specific and seasonal variations in flagellates grazing on heterotrophic bacteria in the oligotrophic lake Annecy-importance of mixotrophy, FEMS Microb. Ecol., 46, 317-329, 2003.

Duarte, C. M. and Agustí, S.: Experimental test of bacteriaphytoplankton coupling in the Southern Ocean, Limnol. Oceanogr., 50, 1844-1854, 2005.

Evans, C., Archer, S. D., Jacquet, S., and Wilson, W. H.: Direct estimates of the contribution of viral lysis and microzooplankton grazing to the decline of a Micromonas spp. population, Aquat. Microb. Ecol., 30, 207-219, 2003.

Fischer, U. R., Wieltscnig, C., Kirschner, A. K. T., and Velimirov, B.: Contribution of virus-induced lysis and protozoan grazing to benthic bacterial mortality estimated simultaneously in microcosm, Environ. Microbiol., 8, 1394-1407, 2006.

Fortier, L., Le Fèvre, J., and Legendre, L.: Export of biogenic carbon to fish and to deep ocean: the role of large planktonic microphages, J. Plankton Res., 16, 809-839, 1994.

Fuhrman, J. A. and Noble, R. T.: Viruses and protists cause similar bacterial mortality in coastal seawater, Limnol. Oceanogr., 40, 1236-1242, 1995.

Garza, D. R. and Suttle, C. A.: The effect of cyanophages on the mortality of Synechococcus spp. and selection for UV resistant viral communities, Microb. Ecol., 36, 281-292, 1998.

Gasol, J. M. and Duarte, C. M.: Comparative analyses in aquatic microbial ecology: how far do they go, FEMS Microbiol. Ecol., 31, 99-106, 2000.

Gasol, J. M., Doval, M. D., Pinhassi, J., Calderón-Paz, J., GuixaBoixareu, N., Vaqué, D., and Pedró-Alió. C.: Diel variations in bacterial heterotrophic activity and growth in the northwestern Mediterranean Sea, Mar. Ecol. Prog. Ser., 164, 107-124, 1998.

Gong, G. C., Liu, K. K., and Pai, S. J.: Prediction of nitrate concentration from two end member mixing in the Southern East China Sea, Deep-Sea Res., I 15, 827-842, 1995.

Heldal, M. and Bratbak, G.: Production and decay of viruses in aquatic environments, Mar. Ecol. Prog. Ser., 72, 205-212, 1991.

Hewson, I., O`Neil, J. M., Fuhrman, J. A., and Dennison, W. C.: Virus-like particle distribution and abundance in sediments and overlaying waters along eutrophication gradients in two subtropical estuaries, Limnol. Oceanogr., 46, 1734-1746, 2001.

Hofer, J. S. and Sommaruga, R.: Seasonal dynamics of viruses in an alpine lake: importance of filamentous forms, Aquat. Microb. Ecol., 26, 1-11, 2001.

Jacquet, S., Domaizon, I., Personnic, S., Sriram, A., Ram, P., Hedal, M., Duhamel, S., and Sime-Ngando, T.: Estimates of protozoanand viral-mediated mortality of bacterioplankton in Lake Bourget (France), Freshw. Biol., 50, 627-645, 2005.

Jiang, S. C. and Paul, J. H.: Seasonal and diel abundance of viruses and occurrence of lysogeny/bacteriocinogeny in the marine environment, Mar. Ecol. Prog. Ser., 104, 163-172, 1994.

Kimmance, S. A., Wilson, W. H., and Archer, S. D.: Modified dilution technique to estimate viral versus grazing mortality of phytoplankton: limitations associated with method sensitivity in natural waters, Aquat. Microb. Ecol., 49, 207-222, 2007.

Kristiansen, K., Nielsen, H., Riemann, B., and Fuhrman, J. A.: Growth efficiencies of freshwater bacterioplankton, Microb. Ecol., 24, 145-160, 1992.

Landry, M. R. and Hassett, R. P.: Estimating the grazing impact of marine microzooplankton, Mar. Biol., 67, 283-288, 1982.

Middelboe, M. and Lyck, P. G.: Regeneration of dissolved organic matter by viral lysis in marine microbial communities, Aquat. Microb. Ecol., 27, 187-194, 2002.

Middelboe, M., Jørgense, N. O. G., and Kroer, N.: Effects of viruses on nutrient turnover and growth efficiency of non-infected marine bacterioplankton, Appl. Environ. Microbiol., 62, 19911997, 1996.

Nobel, R. T. and Fuhrman, J. A.: Use of SYBR Green I for rapid epifluorescence counts of marine viruses and bacteria, Aquat. Microb. Ecol., 14, 113-118, 1998.

Nobel, R. T. and Fuhrman, J. A.: Rapid virus production and removal as measured with fluorescently labeled viruses as tracers. Appl. Environ. Microbiol., 66, 3790-3797, 2000.

Nobel, R. T., Middelboe, M., and Fuhrman, J. A.: The effects of viral enrichment on the mortality and growth of heterotrophic bacterioplankton, Aquat. Microb. Ecol., 18, 1-13, 1999.

Ortmann, A. C., Metzger, R. C., Liefer, J. D., and Novoveska, L.: Grazing and viral lysis vary for different components of the microbial community across an estuarine gradient, Aquat. Microb. Ecol., 65, 143-157, 2011.

Pace, M. L.: Bacterial mortality and the fate of bacterial production. Hydrobiol., 159, 41-49, 1988.

Parsons, T. R., Maita, Y., and Lalli, C. M.: A manual of chemical and biological methods for seawater analysis, Pergamon Press, New York, 1984.

Pedros-Alio, C., Calderon-Paz, J. I., and Gasol, J. M.: Comparative analysis shows that bacterivory, not viral lysis, controls the abundance of heterotrophic prokaryotic plankton, FEMS Microbiol. Ecol., 32, 157-165, 2000. 
Personnic, S., Domaizon, I., Sime-Ngando, T., and Jacquet, S.: Seasonal variations of microbial abundances and virus-versus flagellate-induced mortality of picoplankton in three peri-alpine lakes, J. Plankton Res., 31, 1161-1171, 2009.

Porter, K. G. and Feig, Y. S.: The use of DAPI for identifying and counting aquatic microflora, Limnol. Oceanogr., 25, 943-948, 1980.

Proctor, L. M., Okubo, A., and Fuhrman, J. A.: Calibrating estimates of phage-induced mortality in marine bacteria: ultrastructual studies of marine bacteriophage development from one-step growth experiments, Mar. Ecol., 25, 161-182, 1993.

Sanders, R. W., Caron, D. A., and Berninger, V. G.: Relationships between bacteria and heterotrophic nanoplankton in marine and freshwaters: an inter-ecosystem comparison, Mar. Ecol. Prog. Ser., 86, 1-14, 1992.

Sherr, B. F., Sherr, E. B., and Pedros-Alio, C.: Simultaneous measurement of bacterioplankton production and protozoan bacterivory in estuarine water, Mar. Ecol. Prog. Ser., 54, 209-219, 1989.

Shiah, F. K. and Ducklow, H. W.: Temperature and substrate regulation of bacterial abundance, production and specific growth rate in Chesapeake Bay, USA, Mar. Ecol. Prog. Ser., 103, 297-308, 1994.

Sime-Ngando, T. and Pradeep Ram, A. S.: Grazer effects on prokaryotes and viruses in a freshwater microcosm experiment, Aquat. Microb. Ecol., 41, 115-124, 2005.

Šimek, K., Macek, M., and Vyhnálek, V.: Uptake of bacteria-size fluorescent particles by natural protozoan assemblage in reservoir, Arch. Hydrobiol. Bein. Ergebn. Limnol., 34, 275-281, 1990.

Sommer, U. and Stibor, H.: Copepoda-Cladocera-Tunicata: the role of three major mesozooplankton groups in pelagic food webs, Ecol. Res., 17, 161-174, 2002.

Steward, G. F., Smith, D. C., and Azam, F.: Abundance and production of bacteria and viruses in the Bering and Chukchi Sea, Mar. Ecol. Prog. Ser., 131, 287-300, 1996.

Suttle, C. A. and Chen, F.: Mechanisms and rates of decay of marine viruses in seawater, App. Environ. Microbiol., 58, 3721-3729, 1992.

Taira, Y., Uchimiya, M., and Kudo, I.: Simultaneous estimation of viral lysis and protozoan grazing on bacterial mortality using a modified virus-dilution method, Mar. Ecol. Prog. Ser., 379, $23-$ 32, 2009.

Tamigneaux, E., Vazquez, E., Mingelbeir, M., Klein, B., and Legendre, L.: Environmental control of phytoplankton assemblages in nearshore marine waters, with special emphasis on phototropic ultraplankton, J. Plankton Res., 17, 1421-1447, 1995.

Tijdens, M., Van de Waal, D. B., Slovackova, H., Hoogveld, H. L., and Gons, H. J., Estimates of bacterial and phytoplankton mortality caused by viral lysis and microzooplankton grazing in a shallow eutrophic lake, Freshw. Biol., 53, 1126-1141, 2008.

Tsai, A. Y., Chiang, K. P., Chang, J., and Gong, G. C.: Seasonal diel variations of picoplankton and nanoplankton in a subtropical western Pacific coastal ecosystem, Limnol. Oceanogr., 50, 12211231, 2005.

Tsai, A. Y., Chiang, K. P., Chang, J., and Gong, G. C.: Seasonal variations in trophic dynamics of nanoflagellates and picoplankton in coastal waters of the western subtropical Pacific Ocean, Aquat. Microb. Ecol., 51, 263-274, 2008.
Tsai, A. Y., Gong, G. C., Sanders, R. W., Wang, C. J., and Chiang, K. P.: The impact of the Changjiang River plume extension on the nanoflagellate community in the East China Sea, Estuar. Coast. Shelf Sci., 89, 21-30, 2010.

Tsai, A. Y., Gong, G. C., Sanders, R. W., Chen, W. H., Chao, C. F., and Chiang, K. P.: Importance of bacterivory by pigmented and heterotrophic nanoflagellates during the warm season in a subtropical western Pacific coastal ecosystem, Aquat. Microb. Ecol., 63, 9-18, 2011.

Tsai, A. Y., Gong, G. C., Sanders, R. W., Chiang, K. P., Huang, J. K., and Chan, Y. F.: Viral lysis and nanoflagellate grazing as factors controlling diel variations of Synechococcus spp. summer abundance in coastal waters of Taiwan, Aquat. Microb. Ecol., 66, 159-167, 2012.

Thouvenot, A., Debroas, D., Richardot, M., and Devaux, J.: Impact of natural metazooplankton assemblage on planktonic microbial communities in a newly flooded reservoir, J. Plankton Res., 21, 179-199, 1999.

Vargas, C. A. and González, H. E.: Plankton community structure and carbon cycling in a coastal upwelling system. I. Bacteria, microprotozoans and phytoplankton in the diet of copepods and appendicularians, Aquat. Microb. Ecol., 34, 151-164, 2004.

Weinbauer, M. G. and Höfle, M. G.: Significance of viral lysis and flagellate grazing as factors controlling bacterioplankton production in a eutrophic lake, Appl. Environ. Microbiol., 64, 431-438, 1998.

Weinbauer, M. G. and Peduzzi, P.: Significance of viruses versus heterotrophic nanoflagellates for controlling bacterial abundance in the northern Adriatic Sea, J. Plankton Res., 17, 1851-1856, 1995.

Weisse, T. and Scheffel-Moeser, U.: Growth and grazing loss rates in single-celled Phaeocystis sp. (Prymnesiophyceae), Mar. Biol., 106, 153-158, 1990.

Wells, L. E. and Deming, J. W.: Significance of bacterivory and viral lysis in bottom waters of Franklin Bay, Canadian Arctic, during winter, Aquat. Microb. Ecol., 43, 209-221, 2006.

Wilhelm, S. W. and Suttle, C. A.: Viruses and nutrient cycles in the sea, Biosci., 49, 781-788, 1999.

Wilhelm, S. W., Weinbauer, M. G., Suttle, C. A., and Jeffrey, W. H.: The role of sunlight in the removal and repair of viruses in the sea, Limnol. Oceanogr., 43, 586-592, 1998.

Wilhelm, S. W., Brigden, S. M., and Suttle, C. A.: A dilution technique for the direct measurement of viral production: a comparison in stratified and tidally mixed coastal waters, Microb. Ecol., 43, 168-173, 2002.

Wommack, K. E. and Colwell, R. R.: Virioplankton:viruses in aquatic ecosystems, Microbiol, Mol. Biol. Rev., 64, 69-114, 2000.

Worden, A. Z. and Binder, B. J.: Application of dilution experiments for measuring growth and mortality rates among Prochlorococcus and Synechococcus populations in oligotrophic environments, Aquat. Microb. Ecol., 30, 159-174, 2003.

Work, K., Havens, K., Sharstein, B., and Therese, E.: How important is bacterial carbon to planktonic grazers in a turbid, subtropical lake?, J. Plankton Res., 27, 357-372, 2005. 